\title{
Technological aspects of ore preconcentration with X-ray fluorescence separation
}

\author{
Evgenii F. Tsypin ${ }^{1}$, Tatiana lu. Ovchinnikova ${ }^{1 *}$, \\ Tatiana A. Efremova ${ }^{2}$, Dmitrii B. Elizarov ${ }^{3}$ \\ ${ }^{1}$ Ural State Mining University, Ekaterinburg, Russia \\ 2 JSC Uralmechanobr, Ekaterinburg, Russia \\ ${ }^{3}$ Ural State University of Economics, Ekaterinburg, Russia \\ *e-mail: tt2979@yandex.ru
}

\begin{abstract}
Object and aim of research. By eliminating coarse tailings, preconcentration may increase the content of valuable components in ore at the input of the processing plant with or without throughput reduction. The output of preconcentration tailings therefore determines the reduction level of operating costs. Technological and economic benefit may be significant with high prime cost of deep processing; it is connected with the costs of power-consuming processes of crushing, grinding, dewatering, as well as for reagents and material.
\end{abstract}

Research aims to study main technological factors which influence the effectiveness of ore preconcentration with $X$-ray fluorescence separation.

Methodology. The present research uses technological calculation of preconcentration with X-ray fuorescence separation (XRFS) at various granulometric characteristics of Run-of-Mine Ore and crushed ore, inhomogeneity analysis of components content in a lump with material size variation, experimental research on the study of sorted classes number influence on the indicators of separation with the use of XRFS in preconcentration technologies.

Results and the scope of results. Technological indicators of preconcentration with X-ray fluorescence separation are calculated for various granulometric characteristics of ore which comes to concentration. The obtained data allow to recommend XRFS in maximum size. The influence is revealed of the number of the sorted sorted classes on the total yield of preconcentration tailings. Maximum size of the concentrated material should be taken into account when choosing the number of sorted classes. Research results may be applied when developing the technologies of mineral raw material preconcentration with $X$-ray fluorescence separation.

Summary. The effectiveness of ore separating system operation is largely determined by the quality of ore preparation by granulometric composition both at actual mining (drilling and blasting operations) and crushing-screening at ore separating systems. The proposed approach allows to quantitatively estimate the influence of the number of sorted classes on the effectiveness of preconcentration with $X$-ray fuorescence separation and explain the choice of the number and the boundaries of sorted classes sizes.

Key words: preconcentration; X-ray fluorescence separation; ore sorting system; technology; inhomogeneity in a lump; granulometric characteristics; the number of the sorted classes.

Introduction. Ore preliminary processing is a dynamically developing field of mineral processing. It is largely due to steady depletion of ore stock, mining intensification, involving ore from remote deposits into treating at the currently operating factories, transference of initial processing to pits and underground mines, increased need for feedstock of metallurgical, chemical and construction industry. In Russia [1,2] and abroad [3-7] much attention has been recently paid to the problems 
of preliminary processing of a wide variety of mineral and technogenic raw material basically aimed at creating advantageous technological, economic and ecological conditions for the mined rock treating in further deep processing [2].

Depending on the character of ore, the level of phases disclosure, the content of the principal valuable component, washability indicators, and requirements to the final product, the following technological tasks may be solved at the stage of preliminary processing: coarse final tailings (preconcentration) disposal with further grinding and deep processing of preliminary processing concentrates; ore separation into technological types which are processed according to different flowcharts after grinding; coarse sellable concentrates dressing with further grinding and deep processing of tailings (middlings) of preliminary processing [2].

Preliminary concentration is an important part of technologies at base ore processing. Current tendency towards the reduction of valuable components content in ore may be partly balanced out by the increased capacity of processing plants. Another way to improve the economy of processing technology is to use preconcentration to increase components content in ore which comes to deep processing. Preconcentration is effective when new remote deposits are involved in treating. It is relevant for the mills which exhausted deposits near the processing plant. In this case, ore sorting systems (RSS) are situated in the vicinity of new mines, thus reaching cost reduction for ore transportation to the factory. Preliminary concentration with the same effect can also be used in underground mining.

Technological and economic benefit may be significant with high prime cost of deep processing. By eliminating coarse tailings, preconcentration may increase the content of valuable components in ore at the input of the processing plant with or without throughput reduction. Preconcentration tailings output therefore determines the reduction level of operating costs. Additionally, by means of increasing the content of components, for instance, in flotation feed, technological indicators of flotation processing may improve [2].

Gravity (jigging and dense medium separation), data or sensor (X-ray fluorescence (XRF), X-ray absorption, radiometric, radio-frequency resonance, and optical) methods and washing are used for preliminary concentration $[2,8,9]$.

Currently, the most promising and universal method of preliminary processing is $\mathrm{X}$-ray fluorescence separation (XRFS) which allows sorting by the content of chemical elements [8]. Modern X-ray fluorescence separators fulfill the one-lump-at-a-time mode of stock feed in several parallel passes.

$\mathrm{X}$-ray radiometric (X-ray fluorescence) separation is successively used in uranium $[10,11]$, gold-containing $[8,12]$, copper-zinc $[2,8]$ ore processing; the prospectiveness of its use for many types of mineral feedstock [8], including diamonds [13], coppernickel [8], lead-zinc [14], polymetallic [8], manganese [8], chrome [8] ore, quartz [15] and quartzites [8].

The analysis of technological features of X-ray radiometric mineral processing provides a much more complete insight of the given process, which allows applying this method effectively.

Research aims to study main technological factors which influence the effectiveness of ore preconcentration with X-ray fluorescence separation.

Methodology and results. The present research uses technological calculation of preconcentration with X-ray fluorescence separation (XRFS) at various granulometric characteristics of Run-of-Mine Ore and crushed ore, the analysis of inhomogeneity of components content in a lump with material size variation, experimental research on the study of sorted classes number influence on the indicators of separation with the use of XRFS in preconcentration technologies. 
Let us consider basic technological factors which determine the possibility for the successful application of preliminary X-ray radiometric processing of raw material with the use of X-ray fluorescence separation.

A characteristic property of preliminary concentration with the use of XRFS is Runof-Mine Ore preparation by size. Preparation includes ore crushing up to the required maximum size, screening with division into the sorted classes and unsortable class separation. X-ray characteristics (analytical parameters), measured at sorting, serve to estimate components content in individual lumps. In various sorted classes the values of analytical parameters depend on the size of the lumps [16]. This fact should be taken into account when choosing the number and the boundaries of the sorted classes.

Preconcentration products are characterized by incomplete disclosure of mineral phases [1]. In coarse material, there are the lumps of rock minerals that are usually in the shape of the monomineral lumps, as soon as the rock phase in ore is more often represented by larger aggregates, and being the prevailing phase, it discloses at larger sizes [17].

In most instances, additional disclosure of mineral complexes does not happen at size reduction within the range of the sorted class $(-350+20 \mathrm{~mm})$. The advantage of additional disclosure of ore mineral phases by crushing stages and at size reduction is not evident. The indicators of lump inhomogeneity of copper-bearing ore of a number of deposits may serve as an example (table 1).

Table 1. Contrast indicators in copper-bearing ore in different classes of size Таблица 1. Показатели контрастности медьсодержащих руд в различных классах крупности

\begin{tabular}{c|c|c|c|c|c|c|c|c|c}
\hline \multirow{2}{*}{ Size class, mm } & \multicolumn{7}{|c}{ Number of sample } \\
\cline { 2 - 9 } & 1 & 2 & 3 & 4 & 5 & 6 & 7 & 8 \\
\hline+50 & 0.98 & 0.54 & 1.36 & 1.31 & 1.01 & 1.06 & 079 & 0.83 \\
$-50+25$ & 1.03 & 0.64 & 1.09 & 1.06 & 1.04 & 1.11 & 0.67 & 0.59 \\
$-25+13$ & 1.03 & 0.57 & 1.21 & 0.85 & 1.15 & 0.98 & 0.62 & 0.65
\end{tabular}

The measure of components content variation in lumps may be V. A. Mokrousov contrast indicator [18], the value of which may theoretically vary from 0 (complete absence of contrast corresponding to the equality of components content in all lumps of the sorted material) to 2 (the share of lumps with zero content tends to 1 , and complete disclosure of mineral phases can be observed). Data presented in table 1 do not show significant growth of the contrast indicator with size reduction, thus proving the absence of additional disclosure of mineral phases at size reduction.

During the course of a special experiment, the sample of $-200+100 \mathrm{~mm}$ class was divided into two parts. 100 lumps of one part were analysed for valuable components comtent, while the lumps of the other part were crushed to $-50 \mathrm{~mm}$ size, $-50+25 \mathrm{~mm}$ class was selected from this part, and 100 lumps of this class were analysed for valuable components content. Then, the mean values of components content and RMS deviations were calculated (table 2). RMS deviations of components content in the lumps of $-50+25 \mathrm{~mm}$ class and in the lumps of $-200+100 \mathrm{~mm}$ class are almost the same.

For that reason, if there is no significant disclosure of mineral phases with size reduction of the sorted material, it is necessary to meet the principle of "no extra crushing" when preparing for X-ray radiometric processing and minimize the need to overcrush the material, then it is advisable to process the material in the size, which is most acceptable for X-ray radiometric separators $(300-350 \mathrm{~mm})$. Therefore, material coming to preconcentration may be of this particular size.

With proper scheme and modes of ore preparation to further separation, there is reduction in the output of the unsortable class and redistribution of the sorted materials 
into coarse sorted classes. In this case, extracted ore should be crushed to $300-350 \mathrm{~mm}$ before X-ray radiometric separation with further screening for sorted classes and unsortable class disposal. In some instances, preliminary screening with oversize product crushing should be provided in the open cycle up to the maximum size according to technological characteristics of separators $(300-350 \mathrm{~mm})$. If there is the disclosure of phases in the smaller size, then maximum size may be reduced.

In the instances where there are primarily valuable components transferring into finer classes, coarse classes sorting becomes more effective, i. e. makes it possible to increase the output of coarse tailings and reduce the content of valuable components within them. This is a favourable occasion. In case the prevailing transfer is the transfer of the rock phase into the unsortable class, then only the sorting concentrate without the unsortable class may become the concentrate of the ore sorting system. In this case the conditions of sorting become complicated, as soon as the content of valuable components in its feed increases.

Table 2. Comparison of component content inhomogeneity in the lumps of $-200+100 \mathrm{~mm}$ class of copper-zinc ore and $-\mathbf{5 0}+\mathbf{2 5} \mathrm{mm}$ class lumps obtained from it when crushing in a jaw crusher

Таблица 2. Сопоставление неоднородности содержаний компонентов в кусках класса $-200+100$ мм медно-цинковой руды и полученных из них кусков класса $-50+25$ мм при дроб̆лении в щековой дробилке

\begin{tabular}{c|c|c|c|c|c|c}
\hline \multirow{2}{*}{ Size class, mm } & \multicolumn{2}{|c|}{ Average content in a sample, \% } & \multicolumn{3}{c}{ RMS deviation, \% } \\
\cline { 2 - 7 } & Copper & Zinc & Sulfur & Copper & Zinc & Sulfur \\
\hline$-200+100$ & 0.90 & 1.84 & 14.00 & 1.44 & 4.81 & 10.69 \\
$-50+25$ & 0.91 & 1.33 & 14.98 & 1.56 & 4.04 & 11.13
\end{tabular}

Granulometric characteristic of raw material coming into the ore sorting system is important for technological and economic evaluation of effective technology. Both the maximum size of a lump and the prevalence of coarse or fine size classes are the important factors. The type of characteristics is determined by physical-mechanical properties of ore and the parameters of drilling and blasting operations at rock mass breaking [19].

As soon as the granulometric composition of the separated material is influenced by the granulometric composition of the blasted rock mass, proper organization of mining (especially drilling and blasting) operations together with the optimization of the scheme and the modes of ore preparation for separation, is an important factor of ore distribution into size classes.

Granulometric characteristic of the incoming ore determines the potential output of the sorted classes and potential capital costs, the level of which largely depends on the number of the applied X-ray fluorescent separators.

In order to study the influence of the granulometric characteristic on the technological indicators of preconcentration separation, hypothetic aggregate granulometric characteristics "with the plus sign" were built and calculated with apparently different strength characteristics (fig. 1) with the following values of maximum size $d_{\max }$ : 300,200 and $100 \mathrm{~mm}$ and different output of the unsortable class. For more accuracy, relative size $d / d_{\max }$ is accepted from 0 to 1 with spacing 0.01 .

The output of the unsortable class of $-25+0 \mathrm{~mm}$ for the calculated characteristics differs and depends both on the type of the characteristic, i. e. physical-mechanical properties of rock, and on the maximum size. For granulometric characteristic I, which corresponds to hard ore, the output of the unsortable class varies from 2.4 to $19.65 \%$ depending on the maximum size; for characteristic II, which corresponds to medium- 
hard ore, it varies from 22.12 to $52.76 \%$, and for characteristic III, which corresponds to soft ore, it varies from 40.95 to $67.92 \%$. Fig. 1 shows the boundaries of the unsortable class for the three values of the maximum size. Depending on the maximum size, sorted classes were chosen and their output was calculated for the obtained hypothetic characteristics.

To estimate the technological indicators of preconcentration separation, the circuit inventory was calculated of the typical layout of ore sorting system (fig. 2) for various granulometric characteristics of ore coming to processing.

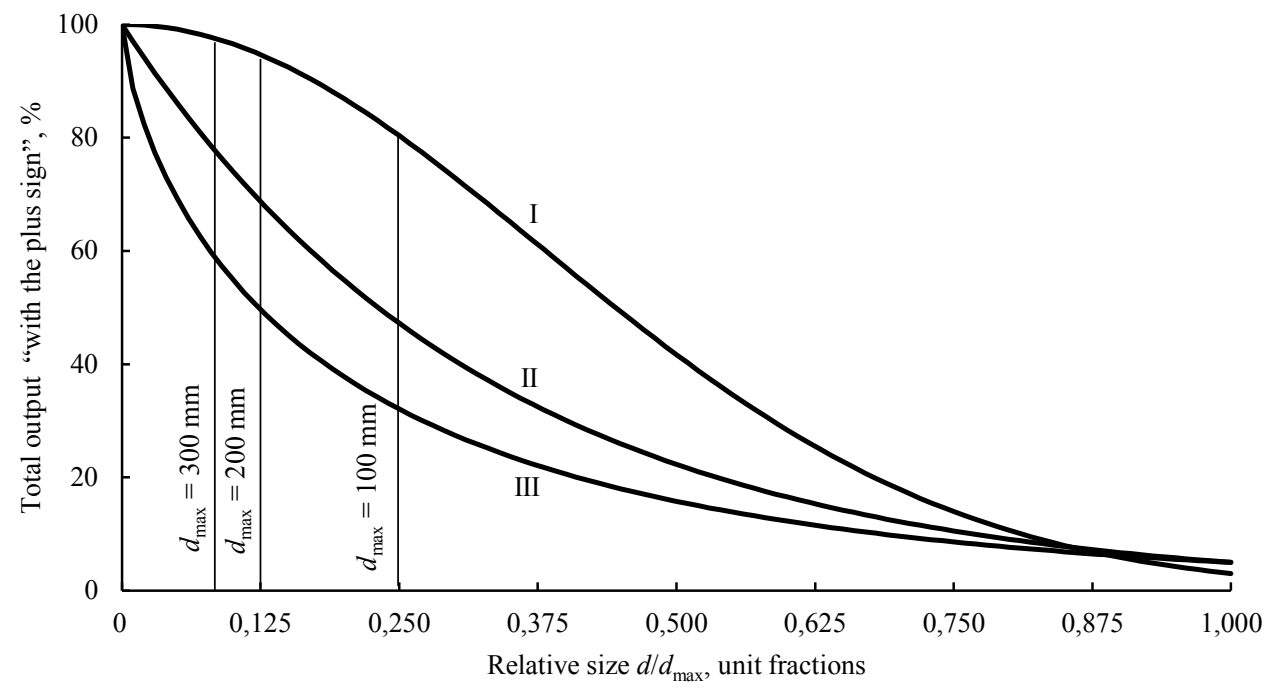

Fig. 1. Aggregate cumulative granulometric characteristics "with the plus sign" Рис. 1. Суммарные гранулометрические характеристики «по плюсу»

When calculating the circuit inventory the following notation has been accepted: $\gamma_{\mathrm{uc}}$ - the output of the unsortable class, unit fractions, given by the type of granulometric characteristic; $\gamma_{\mathrm{s}}-$ the output of the sorted class, unit fractions, $\gamma_{\mathrm{s}}=1-\gamma_{\mathrm{uc}}$; $\gamma_{\mathrm{c}}$ - the output of the separation concentrate, unit fractions; $\gamma_{\mathrm{c}}=A\left(1-\gamma_{\mathrm{uc}}\right)$, where $A$ - the share of concentrate output to the output of the sorted class, unit fractions; $\gamma_{\mathrm{t}}-$ the output of separation tailings, unit fractions; $\gamma_{\mathrm{t}}=(1-A)\left(1-\gamma_{\mathrm{uc}}\right)$; $\gamma_{\text {oss }}$ - the output of the concentrate of the ore sorting system, unit fractions, $\gamma_{\mathrm{OSS}}=\gamma_{\mathrm{uc}}+\gamma_{\mathrm{c}} ; \alpha, \alpha_{\mathrm{uc}}-$ mass fraction of the component in the initial product and the unsortable class, given equal; $\beta_{c}$ - mass fraction of the component in separation concentrate, $\%$, directly proportional to concentration level $k: \beta_{\mathrm{c}}=k \alpha ; \vartheta$-mass fraction of the component in separation tailings, $\%, \vartheta=\left(1 \alpha-\gamma_{\mathrm{uc}} \alpha_{\mathrm{uc}}-\gamma_{\mathrm{c}} \beta_{\mathrm{c}}\right) / \gamma_{\mathrm{t}} ; \beta_{\mathrm{oss}}-$ mass fraction of the component in the concentrate of the ore sorting system, $\%$, $\beta_{\text {OSS }}=\left(1 \alpha-\gamma_{t} 9\right) / \gamma_{\text {oss }}$.

Mass fractions of the component in separation concentrate, unsortable class and the Run-of-Mine Ore are thus similar for all variants of the circuit inventory.

In table 3 , the results of the circuit inventory are presented for three values of unsortable class output (one for each type of granulometric characteristic).

As soon as the unsortable class is combined with separation concentrate, the quantity of this class in $\gamma_{\mathrm{s}}$ Run-of-Mine Ore for sorting will influence the quality of the final concentrate and the output of ore sorting system tailings $\gamma_{t}$. So, with excessive secondary crushing of the initial (III / $100 \mathrm{~mm}$ ), the quality of OSS concentrate is $1.11 \%$, and the output of tailings is not more than $13 \%$, which indicates low effectiveness of preconcentration application in this case. In case the output of the unsortable class 
(I / $300 \mathrm{~mm}$ ) is minimal, the quality of the concentrate reaches $1.48 \%$ with tailing output more than $39 \%$, which can point to the advisability of preconcentration application.

The choice of the analytical parameters also influences the effectiveness of separation, as soon as data obtained from a lump can be handled differently. By way of the analytical parameter, which reduces the errors of separation and to a lesser extent depends on the changing measurement geometry of lumps and positional relationship of the measuring system and the lump and lump shape, the intensity spectral ratio in two spectral domains has been chosen: the domain of the secondary characteristic $\mathrm{X}$-radiation and the domain of the scattered primary X-radiation.

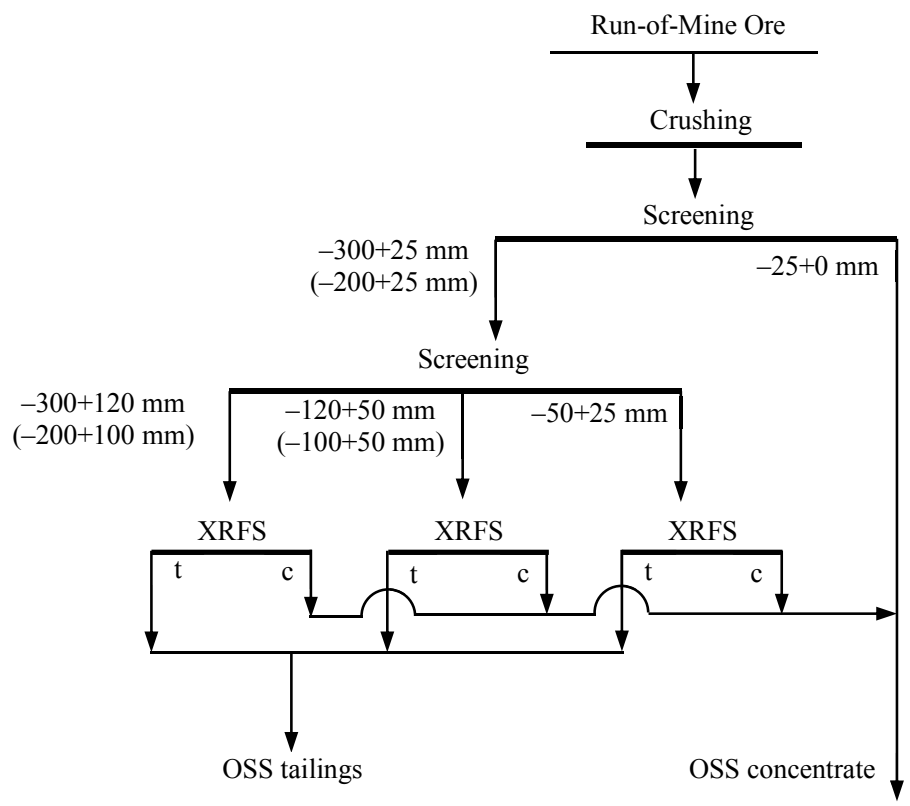

Fig. 2. Typical circuit of the ore sorting system when processing with three sorted classes

Рис. 2. Типовая схема рудосортировочного комплекса при обогащении в трех машинных классах

As far as multicomponent ore processing with the X-ray radiometric method is concerned, particularly when solving preconcentration problem, various algorithms of decision-making are possible concerning lump disposal into this or that product: the disposal algorithm in all components at once with the account of weighting factors or the algorithm with a lump disposal in any component individually. The letter algorithm is more preferable, especially when separating ore with three or more components with a big difference in valuable components mass fractions ratio.

On the other hand, the size of the sorted classes determines the required boundary value of separation parameter and, consequently, influences the effectiveness of separation. The interdependence between ore particles size and the technological indicators of separation is shown by the example of real polymetallic ore. For that purpose, three sorted classes have been singled out from the Run-of-Mine Ore polymetallic ore: $-250+120 ;-75+50 ;-50+30 \mathrm{~mm}$. Each sorted class has been divided into five fractions with the use of X-ray fluorescence separator SRF-100L. Fractioning has been fulfilled with subsequent variation of the boundary value of the separation parameter; in all tests the boundaries were established as similar. 
By way of separation feature, analytical parameter $H$ has been chosen, representing the spectral ratio of intensities in spectral domains: the united domain of the secondary characteristic X-radiation of copper and zinc $N_{\mathrm{Cu}+\mathrm{Zn}}$, lead $N_{\mathrm{Pb}}$ and the domain of the scattered primary radiation $N s$, unit fractions. According to the data from X-ray radiometric fractioning, separation lines have been built; technological indicators with various boundaries of separation were determined with their help, fig. 3 .

With the reduction of an average size of the sorted class lump at one and the same boundary value, mass fraction of the components in separation tailings increases for all size classes. It indicates the need to divide a wide size class into narrower classes and select individual separation thresholds for each class, the class with smaller average size of lump requiring lower boundary value of analytical parameter.

Table 3. Circuit inventory calculation results

Таблица 3. Результаты расчета технологического баланса

\begin{tabular}{|c|c|c|c|}
\hline Type of characteristic, $d_{\max }$ & Product & $\begin{array}{l}\text { Output, unit } \\
\text { fractions }\end{array}$ & Mass share, $\%$ \\
\hline \multirow[t]{5}{*}{ III, $100 \mathrm{~mm}$} & Separation concentrate & 0.1925 & 1.50 \\
\hline & Unsortable & 0.6792 & 1.00 \\
\hline & OSS concentrate & 0.8717 & 1.11 \\
\hline & OSS tailings & 0.1283 & 0.25 \\
\hline & Run-of-Mine Ore & 1.0000 & 1.00 \\
\hline \multirow[t]{5}{*}{ II, $200 \mathrm{~mm}$} & Separation concentrate & 0.4124 & 1.50 \\
\hline & Unsortable & 0.3127 & 1.00 \\
\hline & OSS concentrate & 0.7251 & 1.28 \\
\hline & OSS tailings & 0.2749 & 0.25 \\
\hline & Run-of-Mine Ore & 1.0000 & 1.00 \\
\hline \multirow[t]{5}{*}{$\mathrm{I}, 300 \mathrm{~mm}$} & Separation concentrate & 0.5856 & 1.50 \\
\hline & Unsortable & 0.0240 & 1.00 \\
\hline & OSS concentrate & 0.6096 & 1.48 \\
\hline & OSS tailings & 0.3904 & 0.25 \\
\hline & Run-of-Mine Ore & 1.0000 & 1.00 \\
\hline
\end{tabular}

The study of the influence of X-ray radiometric separation sorted classes number on the technological effectiveness of preconcentration allows to make a conclusion, that preconcentration is the more effective, the greater output of tailings is obtained at separation upholding the restrictions on the content of valuable components in tailings. This indicator is used as a criterion of effectiveness for the technology of preconcentration with X-ray radiometric separation.

Experimental research has been carried out at polymetallic ore with copper content of $0.28 \%$, lead $1.37 \%$, and zinc $5.37 \%$. The sample has been divided into three parts. The first part represented a single sorted class of $-120+30 \mathrm{~mm}$, three classes have been obtained from the second part: $-120+60$ and $-60+30 \mathrm{~mm}$, and three classes from the third one: $-120+75,-75+50$ and $-50+25 \mathrm{~mm}$ sorted classes. Each sorted class undergone fractioning at the X-ray fluorescence separator SRF-100L. Fractioning was carried out with the subsequent variation of the boundary value of separation parameter. Analytical expression for separation parameter takes the following form:

$$
H=\left(N_{\mathrm{Cu}+\mathrm{Zn}}+N_{\mathrm{Pb}}\right) / N s \text {. }
$$



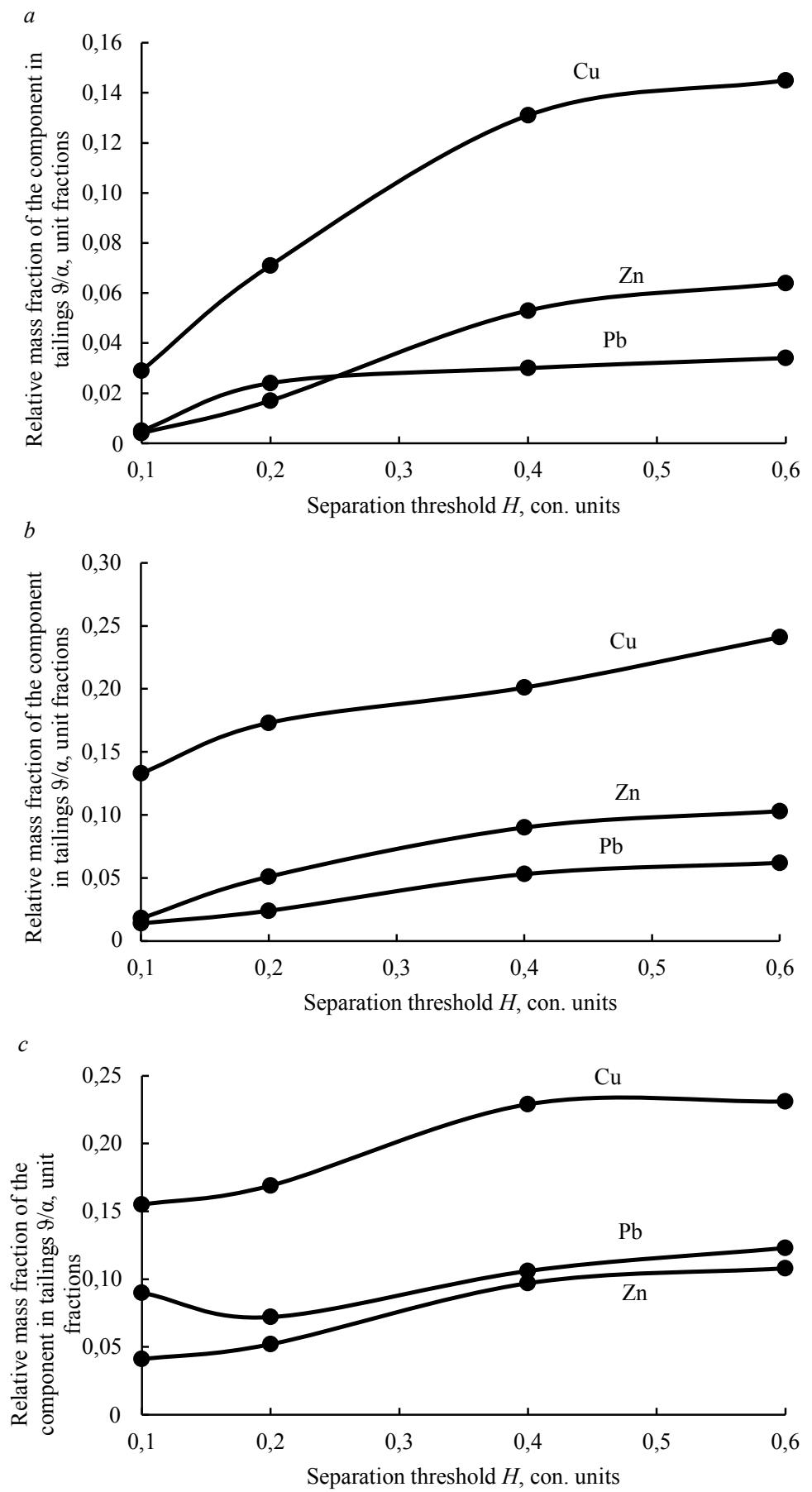

Fig. 3. The variation of the valuable component mass fraction in tailings with the growth of the separation threshold:

$a$ - class $-250+120 \mathrm{~mm}\left(d_{\mathrm{av}}=185 \mathrm{~mm}\right) ; b-$ class $-75+50 \mathrm{~mm}\left(d_{\mathrm{av}}=62,5 \mathrm{~mm}\right)$;

Рис. 3. Изменение массовой доли ценных компонентов в хвостах с ростом порога разделения:

$a-$ класс $-250+120$ мм $\left(d_{\mathrm{cp}}=185 \mathrm{мM}\right) ; b-$ класс $-75+50$ мм $\left(d_{\mathrm{cp}}=62,5 \mathrm{мм}\right)$; $c$ - класс $-50+30$ мм $\left(d_{\mathrm{cp}}=40\right.$ мм $)$ 
Output and mass fractions of copper, lead and zinc have been determined for each fraction. For the samples, separated in two or three sorted classes with the account of each class share, the outputs of fractions, weighted average contents of components in elementary and cumulated fractions in tailings have been determined.

At fig. 4, for various number of sorted classes, separation indicators have been represented both for each component separately at various restrictions on the contents of different components in tailings, and when meeting the restrictions on the content of all three components in tailings simultaneously.

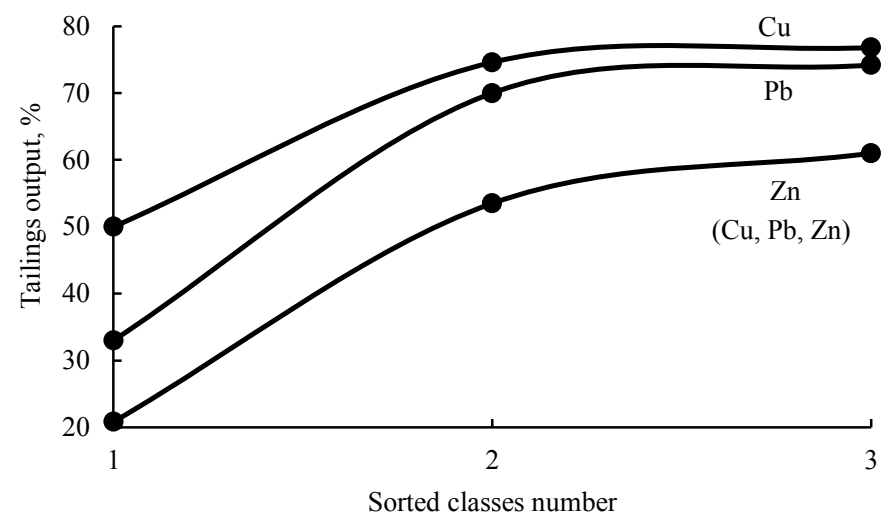

Fig. 4. Tailings output at various number of the sorted classes and equal restrictions by components content in XRFS' tailings

Рис. 4. Выход хвостов при различном числе машинных классов и равных ограничениях по содержанию компонентов в хвостах РФС

The values of components contents in flotation tailings at an operating factory, processing the studied ore, were accepted as reference by the level of restrictions in tailings of XRS.

The conformity of sorting indicators has been detected when separating by three components and separating by zinc; it is explained by the significant content of zinc compared to other components and mild content restrictions (0.5\% GGS).

Run-of-Mine Ore division into two sorted classes promotes to rapid increment in the output of separation tailings; increase in the number of sorted classes from two to three also promotes to the output of tailings by to a lesser degree.

Summary. The effectiveness of ore separating system operation is largely determined by the quality of ore preparation by granulometric composition both at actual mining (drilling and blasting operations) and crushing-screening at ore separating complexes. If there is no significant increase in lump content inhomogeneity with the reduction of ore size, the size of the sorted material should be increased up to the maximum, which corresponds to the technical characteristics of separators.

The proposed approach allows to quantitatively estimate the influence of the number of sorted classes on the effectiveness of preconcentration with X-ray fluorescence separation, including multicomponent ore, and explain the choice of their sizes number and boundaries. The approach is especially effective at a wide range of size of the sorted material.

1. Tsypin E. F. Preliminary processing. Izvestiya vysshikh uchebnykh zavedenii. Gornyi zhurnal = News of the Higher Institutions. Mining Journal. 2001; 4-5: 82-104.

2. Tsypin E. F. Dressing in the stages of ore preparation. Ekaterinburg: UrSMU Publishing; 2015. (In Russ.)

3. Maksimov I. I. XXVII International Mineral Processing Congress. Part 1. Obogashchenie Rud = Mineral Processing. 2015; 3: 3-11. (In Russ.) 
4. Maksimov I. I. XXVII International Mineral Processing Congress. Part 2. Obogashchenie Rud = Mineral Processing. 2015; 6: 50-58. (In Russ.)

5. Gleeson D. Preceding processing // International Mining. March, 2019. P. 82-87.

6. Moore P. Processing performance // International Mining. January, 2018. P. 66-73.

7. Härkki K. Overcoming sustainability challenges of future concentrator plants. Proceedings of the XXVII International Mineral Congress. Santiago, Chile, 2014. Chapter 1. Plenary Presentations. P. 2-22.

8. Fedorov Iu. O., Katser I. U., Korenev O. V., Korotkevich V. A., Tsoi V. P., Kovalev P. I., Fedorov M. Iu., Popovskii N. S. Experience and practice of X-ray radiometric ore separation. Izvestiya vysshikh uchebnykh zavedenii. Gornyi zhurnal = News of the Higher Institutions. Mining Journal. 2005; 5: 21-37. (In Russ.)

9. Kolacz J. Sensor based sorting with signal pattern recognition: the new powerful tool in mineral processing // Proceedings of the XXVII International Mineral Congress. Santiago, Chile, 2014. Chapter 16. Classification, screening and sorting. P. 106-115.

10. Litvinenko V. G., Sukhanov R. A., Tirskii A. V., Tupikov D. G. Improvement of the technology of X-ray radiometric concentration of uranium ores. Gornyi zhurnal = Mining Journal. 2003; 8: 54-58. (In Russ.)

11. Kolesaev V. B., Litvinenko V. G., Kultyshev V. I. Combined technology for processing of poor uranium ore. Gornyi zhurnal = Mining Journal. 2008; 8: 50-53. (In Russ.)

12. Sanakulov K. S., Rudnev S. V. Complex of X-ray radiometric dressing of sulphide ore at Kokpatas deposit. Gornyi vestnik Uzbekistana = Mining News of Uzbekistan. 2010; 1 (40): 3-7. (In Russ.)

13. Rakhmeev R. N., Voiloshnikov G. I., Fedorov Iu. O., Chikin A. Iu. Results of the experiments over the X-ray radiometrical separator for diamond-bearing concentrates processing. Izvestiya vysshikh uchebnykh zavedenii. Gornyi zhurnal = News of the Higher Institutions. Mining Journal. 2017; 5: 80-88. (In Russ.)

14. Sanakulov K. S., Rudnev S. V., Kantsel A. V. Regarding the possibility of mining Uchquloch deposit with the use of lead-zinc ore X-ray radiometric separation technology. Gornyi vestnik Uzbekistana= Mining News of Uzbekistan. 2011; 1 (44): 17-20. (In Russ.)

15. Shemiakin V. S., Skopov S. V., Mankovskii R. V., Krasilnikov P. A., Mamonov R. S. Preliminary concentration of quartz raw material at Kyshtym deposit. Izvestiya vysshikh uchebnykh zavedenii. Gornyi zhurnal = News of the Higher Institutions. Mining Journal. 2016; 8: 74-79. (In Russ.)

16. Efremova T. A. The influence of the size of classes on the boundary value of the analytical parameters of X-ray fluorescence separation of polymetallic ore. In: Ural mining school to the regions: proceedings of the scientific and practical conference for young scientists and students. Ekaterinburg: UrSMU Publishing; 2018. p. 266-267. (In Russ.)

17. Kozin V. Z. Ore dressability research. Ekaterinburg: UrSMU Publishing; 2016. (In Russ.)

18. Mokrousov V. A., Golbek G. R., Arkhipov O. A. Theoretical fundamentals of radiometric dressing of radioactive ore. Moscow: Nedra Publishing; 1968. (In Russ.)

19. Latyshev O. G. Methods and means of studying high-speed processes. Ekaterinburg: UrSMU Publishing; 2007. (In Russ.)

Received 4 July 2019

\section{Information about authors:}

Evgenii F. Tsypin - DSc (Engineering), Professor, professor of the Department of Mineral Processing, Ural State Mining University. E-mail: tsipin.e@mail.ru

Tatiana Iu. Ovchinnikova - PhD (Engineering), Associate professor, associate professor of the Department of Mineral Processing, Ural State Mining University. E-mail: tt2979@yandex.ru

Tatiana A. Efremova - researcher, Processing Department, Laboratory of Nonferrous Metal Ore and Technogenic Raw Material Processing, JSC Uralmechanobr. E-mail: efremova_ta@umbr.ru

Dmitrii B. Elizarov - PhD (Engineering), Associate professor, associate professor of the Department of Business IT, Ural State University of Economics. E-mail: elizarovdb@yandex.ru

DOI: $10.21440 / 0536-1028-2019-7-101-112$

\section{Технологические аспекты предварительной концентрации руд с использованием рентгенофлуоресцентной сепарации}

Цыпин Е. Ф., Овчинникова Т. Ю. ${ }^{1}$, Ефремова Т. А. ${ }^{2}$, Елизаров Д. Б. ${ }^{3}$

1 Уральский государственный горный университет, Екатеринбург, Россия.

${ }^{2}$ Научно-исследовательский и проектный институт «Уралмеханобр», Екатеринбург, Россия.

3 Уральский государственный экономический университет, Екатеринбург, Россия.

\section{Peфepam}

Предмет и цель работы. Предварительная концентрация может позволить за счет удаления крупнокусковых хвостов повысить содержание ценных компонентов в руде на входе обогатитель- 
ной фабрики при снижении либо без снижения объема переработки. Таким образом, выход хвостов предварительной концентрации определяет уровень снижения эксплуатационных расходов. Технологический и экономический эффект может быть весьма значительным при высокой себестоимости глубокого обогащения, что связано с затратами на энергоемкие процессы дробления, измельчения, обезвоживания, на реагенты и материаль.

Целью данной работы является изучение основных технологических факторов, влияющих на эффективность предварительной концентрации руд с использованием рентгенофлуоресцентной сепарации.

Методология. В работе использованы расчеты технологических показателей предварительной кониентрации с применением рентгенофлуоресиентной сепарации (РФС) при различных гранулометрических характеристиках исходной и дробленой руды, анализ неоднородности покусковых содержаний компонентов с изменением крупности материала, экспериментальные исследования по изучению влияния числа машинных классов сортировки на показатели разделения при использовании РФС в технологиях предварительной концентрации.

Результаты и область применения результатов. Рассчитаны технологические показатели предварительной концентрации с применением РФС для различных гранулометрических характеристик руды, поступающей на обогащение. Полученные показатели позволяют рекомендовать проведение РФС в максимальной крупности. Также выявлено влияние числа сортируемых машинных классов на суммарный выход хвостов предварительной концентрации. В принятии решения по выбору числа машинных классов следует учитывать максимальную крупность обогашаемого материала. Результаты исследований могут быть использованы при разработке технологий предварительной концентрации минерального сырья с применением рентгенофлуоресиентной сепарации.

Выводы. Эффективность работы рудосортировочного комплекса в значительной степени определяется качеством подготовки руды по гранулометрическому составу как при добычных (буровзрывных работах, так и при организации дробления-грохочения в рудосортировочных комплексах. Изложенный подход позволяет количественно оченить влияние числа машинных классов на эффективность предварительной концентрации с использованием рентгенорадиометрической сепарации и обосновать выбор числа и границ крупности машинных классов.

Ключевые слова: предварительная концентрация; рентгенофлуоресиентная сепарация; рудосортировочный комплекс; технология; покусковая неоднородность; гранулометрическая характеристика; число сортируемьх классов.

\section{БИБЛИОГРАФИЧЕСКИЙ СПИСОК}

1. Цыпин Е. Ф. Предварительное обогащение // Известия вузов. Горный журнал. 2001. № 4-5. C. $82-104$.

2. Цыпин Е. Ф. Обогащение в стадиях рудоподготовки. Екатеринбург: УГГУ, 2015. 303 с.

3. Максимов И. И. XXVII Международный конгресс по обогащению полезных ископаемых (часть 1) // Обогащение руд. 2015. № 3. С. 3-11.

4. Максимов И. И. XXVII Международный конгресс по обогащению полезных ископаемых (часть 2) // Обогащение руд. 2015. № 6. С. 50-58.

5. Gleeson D. Preceding processing // International Mining. March, 2019. P. 82-87.

6. Moore P. Processing performance // International Mining. January, 2018. P. 66-73.

7. Härkki K. Overcoming sustainability challenges of future concentrator plants. Proceedings of the XXVII International Mineral Congress. Santiago, Chile, 2014. Chapter 1. Plenary Presentations. P. 2-22.

8. Федоров Ю. О., Кацер И. У., Коренев О. В., Короткевич В. А., Цой В. П., Ковалев П. И., Федоров М. Ю., Поповский Н. С. Опыт и практика рентгенорадиометрической сепарации руд // Известия вузов. Горный журнал. 2005. № 5. С. 21-37.

9. Kolacz J. Sensor based sorting with signal pattern recognition: the new powerful tool in mineral processing // Proceedings of the XXVII International Mineral Congress. Santiago, Chile, 2014. Chapter 16. Classification, screening and sorting. P. 106-115.

10. Литвиненко В. Г., Суханов Р. А., Тирский А. В., Тупиков Д. Г. Совершенствование технологии радиометрического обогащения урановых руд // Горный журнал. 2003. № 8. С. 54-58.

11. Колесаев В. Б., Литвиненко В. Г., Култышев В. И. Комбинированная технология переработки бедных урановых руд // Горный журнал. 2008. № 8. С. 50-53.

12. Санакулов К. С., Руднев С. В. Комплекс рентгенорадиометрического обогащения сульфидных руд месторождения «Кокпатас» // Горный вестник Узбекистана. 2010. № 1(40). С. 3-7.

13. Рахмеев Р. Н., Войлошников Г. И., Федоров Ю. О., Чикин А. Ю. Результаты испытаний рентгенорадиометрического сепаратора для обогащения алмазосодержащих концентратов // Известия вузов. Горный журнал. 2017. № 5. С. 80-88.

14. Санакулов К. С., Руднев С. В., Канцель А. В. О возможности отработки месторождения «Учкулач» с использованием технологии рентгенорадиометрического обогащения свинцово-цинковых руд // Горный вестник Узбекистана. 2011. № 1(44). С. 17-20.

15. Шемякин В. С., Скопов С. В., Маньковский Р. В., Красильников П. А., Мамонов Р. С. Предварительное обогащение кварцевого сырья // Известия вузов. Горный журнал. 2016. № 8. С. 74-79. 
16. Ефремова Т. А. Влияние крупности классов на граничное значение аналитического параметра рентгенофлуоресцентной сепарации полиметаллической руды // Уральская горная школа - регионам: матер. науч.-практ. конф. молодых ученых и студентов. Екатеринбург: УГГУ, 2018. C. 266-267.

17. Козин В. З. Исследование руд на обогатимость. Екатеринбург: УГГУ, 2016. 188 с.

18. Мокроусов В. А., Гольбек Г. Р., Архипов О. А. Теоретические основы радиометрического обогащения радиоактивных руд. М.: Недра, 1968. 162 с.

19. Латышев О. Г. Методы и средства изучения быстропротекающих процессов. Екатеринбург: УГГУ, 2007. $232 \mathrm{c}$.

Поступила в редакцию 4 июля 2019 года

\section{Сведения об авторах:}

Цыпин Евгений Федорович - доктор технических наук, профессор, профессор кафедры обогащения полезных ископаемых Уральского государственного горного университета. E-mail: tsipin.e@mail.ru

Овчинникова Татьяна Юрьевна - кандидат технических наук, доцент, доцент кафедры обогащения полезных ископаемых Уральского государственного горного университета. E-mail: tt2979@yandex.ru

Ефремова Татьяна Александровна - научный сотрудник отдела обогащения лаборатории обогащения руд цветных металлов и техногенного сырья Научно-исследовательского и проектного института «Уралмеханобр». E-mail: efremova_ta@umbr.ru

Елизаров Дмитрий Борисович - кандидат технических наук, доцент, доцент кафедры бизнес-информатики Уральского государственного экономического университета. E-mail: elizarovdb@yandex.ru

Для цитирования: Цыпин Е. Ф., Овчинникова Т. Ю., Ефремова Т. А., Елизаров Д. Б. Технологические аспекты предварительной концентрации руд с использованием рентгенофлуоресцентной сепарации // Известия вузов. Горный журнал. 2019. № 7. C. 101-112 (In Eng.). DOI: 10.21440/0536-10282019-7-101-112

For citation: Tsypin E. F., Ovchinnikova T. Iu., Efremova T. A., Elizarov D. B. Technological aspects of ore preconcentration with X-ray fluorescence separation. Izvestiya vysshikh uchebnykh zavedenii. Gornyi zhurnal = News of the Higher Institutions. Mining Journal. 2019; 7: 101-112. DOI: 10.21440/0536-10282019-7-101-112 